\title{
PEMBIAYAAN GADAI EMAS KONVENSIONAL DAN SYARIAH
}

Oleh

\author{
Laily Nurhayati (lailynurhayati@ymail.com) \\ Radjab Djamali (radjabdjamali@ yahoo.co.id)
}

\begin{abstract}
Financing system used in gold pawn transactions in Indonesia are conventional and shar'i. Conventional system is employed only by pawnshops owned by the government, namely "Pegadaian". Meanwhile,the sharia system is employed by sharia private banks, sharia business units, and sharia pawnshops. Gold mortgage finance at pawnshops is calculated based on the loan amount multiplied by interest multiplied the number of days. Meanwhile, gold mortgage finance at sharia pawnshops and sharia banks as well as Islamic business is calculated based on the estimated value (collateral/gold) multiplied by the interest multiplied by the number of days. The results obtained for the amount of financing (loans) is the same, but smaller nominal interest is obtained when it calculated using the Islamic system. However, the numberof shariadebtors is still very small compared to the conventional debtors.
\end{abstract}

Keywords: Pawn, Gold, Estimates, Financing, Interest, Lease (Ijaroh)

Abstrak

Pembiayaan gadai emas yang dilakukan oleh lembaga keuangan di Indonesia menggunakan prinsip konvensional dan syariah. Prinsipkonvensional diterapkan oleh satusatunya lembaga gadai milik pemerintah yaitu Pegadaian. Sedangkan prinsip syariah diterapkan oleh bank umum syariah atau unit usaha syariah dan pegadaian syariah. Perhitungan pembiayaan gadai emas pada pegadaian berdasarkan jumlah pinjaman dikalikan bunga dikalikan periode. Sedangkan perhitungan pembiayaan gadai emas pada pegadaian syariah dan bank/unit usaha syariah berdasarkan nilai taksiran (jaminanemas) dikalikan biaya ujroh dikalikan periode. Hasil yang didapat untuk jumlah pembiayaan (pinjaman) yang sama nominalnya tetapi lebih kecil jumlah pelunasannya adalah perhitungan dengan menggunakan prinsip syariah. Namun begitu jumlah debitur gadai emas syariah masih sedikit dibandingkan dengan debitur gadai emas konvensional.

Kata Kunci: Pembiayaan, Gadai Emas, Konvensional, Syariah, Debitur 


\section{Pendahuluan}

Pada masa Hindia Belanda sekitar tahun 1928-an sudah ada Undang-undang yang mengatur tentang bisnis gadai. Berdasar Undang-undang itu, gadai hanya boleh dilakukan oleh negara. Pegadaian adalah badan usaha milik negara yang menyediakan dana (penyaluran uang pinjaman) atas dasar hukum gadai untuk meningkatkan kesejahteraan masyarakat terutama golongan menengah ke bawah (PP No 103 Tahun 2000).

Gadai adalah meminjam uang dalam batas waktu tertentu dengan menyerahkan barang sebagai tanggungan, jika telah sampai pada waktunya tidak ditebus, barang itu menjadi hak yang memberi pinjaman (kbbi.web.id).

Gadai adalah suatu hak yang diperoleh seseorang yang berpiutang atas suatu barang bergerak, yang diserahkan kepadanya oleh seorang yang berutang atau oleh seorang lain atas namanya, dan memberikan kekuasaan kepada orang yang berpiutang itu untuk mengambil pelunasan dari barang tersebut secara didahulukan daripada orang-orang yang berpiutang lainnya; dengan pengecualian biaya untuk melelang barang tersebut, dimana seseorang itu harus menggadaikan barangnya untuk mendapatkan uang (wikipedia.org).

Gadai adalah suatu hak yang diperoleh kreditur atau suatu barang bergerak yang diserahkan ke padanya oleh debitur atau oleh kuasanya, sebagai jaminan atas utangnya dan yang memberi wewenang kepada kreditur untuk mengambil pelunasan piutang dari barang itu dengan mendahului kreditur-kreditur lain, dengan pengecualian biaya penjualan sebagai pelaksanaan putusan atas tuntutan mengenai kepemilikan atau penguasaan dan biaya penyelamatan barang itu, yang dikeluarkan setelah barang itu diserahkan sebagai gadai dan yang harus didahulukan (pasal $1150 \mathrm{KUH}$ perdata).

Bunga adalah imbal jasa atas pinjaman uang. Imbal jasa cipal. Persentase dari pokok utang yang dibayarkan sebagai imbal jasa (bunga) dalam suatu periode tertentu disebut "suku 


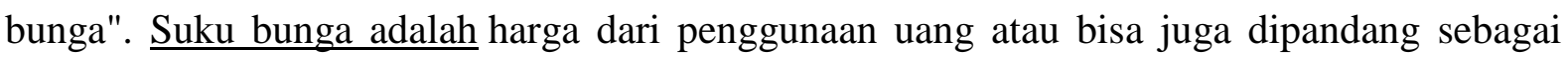
sewa atas penggunaan uang untuk jangka waktu tertentu. Atau harga dari meminjam uang untuk menggunakan daya belinya dan biasanya dinyatakan dalam persen (\%) (wikipedia.org).

Bunga bank dapat diartikan sebagai balas jasa yang diberikan oleh bank yang berdasarkan prinsip konvensional kepada nasabah yang membeli atau menjual produknya. Bunga juga dapat diartikan sebagai harga yang harus dibayar kepada nasabah (yang memiliki simpanan) dengan yang harus dibayar oleh nasabah kepada bank (nasabah yang memperoleh pinjaman). (Kasmir, 2002)

Dalam kegiatan perbankan ada dua macam bunga, yaitu:

1) Bunga Simpanan yaitu bunga yang diberikan oleh bank sebagai balas jasa kepada nasabah/kreditur yang menyimpan uangnya di bank. Dalam hal ini bank harus membayar bunga simpanan (tabungan, deposito dan lain-lain) kepada nasabah.

2) Bunga Pinjaman yaitu bunga yang diberikan oleh bank kepada para peminjam/debitursebagai harga yang harus dibayar oleh debitur kepada bank. Contoh: bunga kredit.

Para ulama bersepakat, hukum gadai secara umum diperbolehkan (Fatwa Dewan Syari'ah Nasional Nomor 25/Dsn-MUI/III/2002). Ini didasari beberapa dalil, di antaranya:

1) Firman Allah, QS. Al-Baqarah [2]: 283:

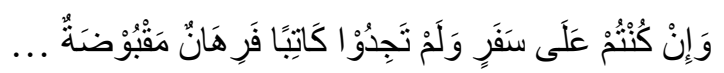

"Dan apabila kamu dalam perjalanan sedang kamu tidak memperoleh seorang juru tulis maka hendaklah ada barang tanggungan yang dipegang ..."

2) Hadis Nabi riwayat al-Bukhari dan Muslim dari 'Aisyah r.a., ia berkata:

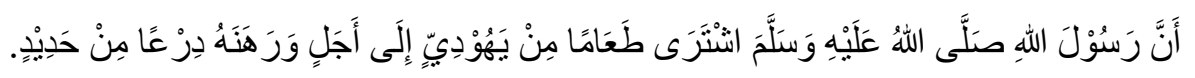


"Sesungguhnya Rasulullah s.a.w. pernah membeli makanan dengan berutang dari seorang

Yahudi, dan Nabi menggadaikan sebuah baju besi kepadanya."

Gadai syariah (rahn) adalah menahan salah satu harta milik nasabah (rahin) sebagai barang jaminan (marhum) atas utang/pinjaman (marhun bih) yang diterimanya. Marhun tersebut memiliki nilai ekonomis. Dengan demikian, pihak yang menahan atau penerima gadai (murtahin) memperoleh jaminan untuk dapat mengambil kembali seluruh atau sebagian piutangnya (Antonio, 2001).

Ar-Rahnu adalah menjadikan barang yang mempunyai nilai harta (nilai ekonomis) sebagai jaminan hutang, hingga pemilik barang yang bersangkutan boleh mengambil hutang. Ar-Rahn berarti juga pledge atau pawn (gadai), yaitu kontrak atau akad penjaminan dan mengikat saat hak penguasaan atas barang jaminan berpindah tangan. Dalam kontrak tersebut, tidak terjadi pemindahan kepemilikan atas barang jaminan. Atau dengan kata lain, merupakan akad penyerahan barang dari nasabah kepada bank sebagai jaminan sebagian atau seluruhnya atas hutang yang dimiliki nasabah. Dengan demikian, pemindahan kepemilikan atas barang hanya terjadi dalam kondisi tertentu sebagai efek atau akibat dari kontrak (Edukasi Syariah, Bank Syariah Mandiri).

Ketentuan Umum Rahn (Fatwa DSN, 2002)

1) Murtahin (penerima barang) mempunyai hak untuk menahan Marhun (barang) sampai semua utang Rahin (yang menyerahkan barang) dilunasi.

2) Marhun dan manfaatnya tetap menjadi milik Rahin. Pada prinsipnya, Marhun tidak boleh dimanfaatkan oleh Murtahin kecuali $\quad$ seizin Rahin, dengan tidak mengurangi nilai Marhun dan pemanfaatannya itu sekedar pengganti biaya pemeliharaan dan perawatannya. 
3) Pemeliharaan dan penyimpanan Marhun pada dasarnya menjadi kewajiban Rahin, namun dapat dilakukan juga oleh Murtahin, sedangkan biaya dan pemeliharaan penyimpanan tetap menjadi kewajiban Rahin.

4) Besar biaya pemeliharaan dan penyimpanan Marhun tidak boleh ditentukan berdasarkan jumlah pinjaman.

5) Penjualan Marhun

a. Apabila jatuh tempo, Murtahin harus memperingatkan Rahin untuk segera melunasi utangnya.

b. Apabila Rahin tetap tidak dapat melunasi utangnya, maka Marhun dijual paksa/dieksekusi melalui lelang sesuai syariah.

c. Hasil penjualan Marhun digunakan untuk melunasi utang, biaya pemeliharaan dan penyimpanan yang belum dibayar serta biaya penjualan.

d. Kelebihan hasil penjualan menjadi milik Rahin dan kekurangannya menjadi kewajiban Rahin.

Pelaksanaan gadai syariah merupakan suatu upaya untuk menampung keinginan masyarakat khususnya umat muslim yang menginginkan transaksi kredit sesuai Syariat Islam. Atas dasar tersebut Bank Indonesia resmi mengeluarkan Surat Edaran Bank Indonesia Nomor 14/7/DPbS tanggal 29 Februari 2012 tentang Produk Qardh Beragun Emas bagi Bank Syariah dan Unit Usaha Syariah. Surat edaran ini mengacu pada Peraturan Bank Indonesia (PBI) Nomor/17/PBI/2008 tentang Produk Bank Syariah dan Unit Usaha Syariah (UUS).

Fatwa Dewan Syari'ah Nasional Nomor 26/Dsn-Mui/Iii/2002 tentang Rahn Emas, memutuskan bahwa:

1) Rahn Emas dibolehkan berdasarkan prinsip Rahn (lihat Fatwa DSN nomor: 25/DSNMUI/III/2002 tentang Rahn). 
2) Ongkos dan biaya penyimpanan barang (marhun) ditanggung oleh penggadai (rahin).

3) Ongkos sebagaimana dimaksud ayat 2 besarnya didasarkan pada pengeluaran yang nyatanyata diperlukan.

4) Biaya penyimpanan barang (marhun) dilakukan berdasarkan akad Ijarah.

Ijarah adalah perjanjian sewa yang memberikan kepada penyewa untuk memanfaatkan barang yang akan disewa dengan imbalan uang sewa sesuai dengan persetujuan dan setelah masa sewa berakhir maka barang dikembalikan kepada pemilik, namun penyewa dapat juga memiliki barang yang disewa dengan pilihan pemindahan kepemilikan atas barang yang disewa dari pihak bank oleh pihak lain (ijarah wa iqtina). (Edukasi Syariah, Bank Syariah Mandiri).

\section{Bahan dan Metode}

Bahan yang dikumpulkan berdasarkan observation yaitu melakukan pengamatan berbagai simulasi pembiayaan gadai emas dari beberapa lembaga keuangan di Indonesia yaitu Pegadaian, Pegadaian Syariah, Bank Syariah Mandiri, Bank Jabar Banten Syariah dan Unit Usaha Syariah Bank CIMB Niaga.

Metode deskriptif untuk menjelaskan perhitungan secara rinci mengenai sistem pembiayaan gadai emas konvensional dan pembiayaan gadai emas syariah.

\section{Hasil dan Pembahasan}

Financing To Value (FTV) adalah perbandingan antara jumlah pembiayaan yang diterima Nasabah dengan nilai emas yang diagunkan Nasabah kepada Bank.

\subsection{Gadai Emas Konvensional (Pegadaian)}

Prinsip gadai emas konvensional memungut biaya dalam bentuk bunga yang bersifat akumulatif dan berlipat ganda. Bunga dihitung berdasarkan jumlah uang pinjaman. Ketentuan Gadai Emas Pegadaian 
1) $\mathrm{FTV}=85 \%$ (emas perhiasan) dan $90 \%$ (logam mulia) dari harga taksiran

2) Jangka Waktu minimal 15 hari (1 periode) maksimal 120 hari (4 bulan) dapat diperpanjang

Tabel 1. Harga Emas Pegadaian

Update: $28-12-2016$

\section{Harga Emas Pegadaian}

\begin{tabular}{lr} 
Denominasi & Harga \\
\hline 1 gram & 586.000 \\
\hline 5 gram & 2.785 .000 \\
\hline 10 gram & 5.520 .000 \\
\hline 25 gram & 13.725 .000 \\
\hline 50 gram & 27.400 .000 \\
\hline 100 gram & 54.750 .000 \\
\hline 250 gram & 136.750 .000 \\
\hline
\end{tabular}

Sumber: http://www.pegadaian.co.id/simulasi-pelunasan-kca.php

Tabel 2. Tarif Sewa Modal Pegadaian

\begin{tabular}{|c|c|c|c|c|c|c|}
\hline \multirow[t]{4}{*}{00} & \multicolumn{6}{|c|}{ Tarif Sewa Modal Pegadaian } \\
\hline & \multicolumn{6}{|c|}{ Pembiayaan KCA (Gadai Konvensional) } \\
\hline & \multirow{2}{*}{ Golongan } & \multicolumn{2}{|c|}{ Uang Pinjaman (UP) } & \multicolumn{2}{|c|}{ Tarif Sewa Modal } & \multirow{2}{*}{$\begin{array}{c}\text { Lama Pinjaman } \\
\text { (hari) }\end{array}$} \\
\hline & & Min & Max & Emas & Non-Emas & \\
\hline & A & 50,000 & 500,000 & $\begin{array}{c}0.750 \% \mathrm{x} \\
\text { UP }\end{array}$ & $\begin{array}{c}0.750 \% \mathrm{x} \\
\text { UP }\end{array}$ & $1 \mathrm{~s} / \mathrm{d} 120$ \\
\hline & B1 & 500,001 & $1,000,000$ & $\begin{array}{c}1.150 \% \mathrm{x} \\
\text { UP }\end{array}$ & $\begin{array}{c}1.150 \% \mathrm{x} \\
\text { UP }\end{array}$ & $1 \mathrm{~s} / \mathrm{d} 120$ \\
\hline & B2 & $1,000,001$ & $2,500,000$ & $\begin{array}{c}1.150 \% \mathrm{x} \\
\text { UP }\end{array}$ & $\begin{array}{c}1.150 \% \mathrm{x} \\
\text { UP }\end{array}$ & $1 \mathrm{~s} / \mathrm{d} 120$ \\
\hline & B3 & $2,500,001$ & $5,000,000$ & $\begin{array}{l}1.150 \% \mathrm{x} \\
\mathrm{UP}\end{array}$ & $\begin{array}{c}1.150 \% \mathrm{x} \\
\text { UP }\end{array}$ & $1 \mathrm{~s} / \mathrm{d} 120$ \\
\hline & $\mathrm{C} 1$ & $5,000,001$ & $10,000,000$ & $\begin{array}{c}1.150 \% \mathrm{x} \\
\text { UP }\end{array}$ & $\begin{array}{c}1.150 \% \mathrm{x} \\
\text { UP }\end{array}$ & $1 \mathrm{~s} / \mathrm{d} 120$ \\
\hline & $\mathrm{C} 2$ & $10,000,001$ & $15,000,000$ & $\begin{array}{c}1.150 \% \mathrm{x} \\
\mathrm{UP}\end{array}$ & $\begin{array}{l}1.150 \% \mathrm{x} \\
\mathrm{UP}\end{array}$ & $1 \mathrm{~s} / \mathrm{d} 120$ \\
\hline & C3 & $15,000,001$ & $20,000,000$ & $\begin{array}{l}1.150 \% \mathrm{x} \\
\mathrm{UP}\end{array}$ & $\begin{array}{c}1.150 \% \mathrm{x} \\
\text { UP }\end{array}$ & $1 \mathrm{~s} / \mathrm{d} 120$ \\
\hline & $\mathrm{D}$ & $20,000,001$ & $1,000,000,000$ & $\begin{array}{c}1.000 \% \mathrm{x} \\
\text { UP }\end{array}$ & $\begin{array}{c}1.150 \% \mathrm{x} \\
\text { UP }\end{array}$ & $1 \mathrm{~s} / \mathrm{d} 120$ \\
\hline
\end{tabular}


Sumber: http://www.pegadaian.co.id/suku-bunga.php?sewa_modal

Contoh: Simulasi Pembiayaan Gadai Emas Konvensional (Pegadaian)

Pada tanggal 1 November 2016, Nasabah membawa emas untuk digadaikan berupa gelang bermata dengan kadar 18 karat dan berat 20 gram. Berapakah jumlah yang harus dibayar, bila Nasabah melunasi pada tanggal 29 Desember 2016 dengan uang pinjaman Rp. $6.000 .000,-?$

Pembahasan:

Periode Gadai : 1 November -29 Desember $=59$ hari $(4$ periode $)$

Taksiran : emas perhiasan 18 Karat berat 20 gram

$=(\mathrm{karat} / 24) \mathrm{x}$ berat emas $\mathrm{x}$ harga emas

$=18 / 24 \times(5.520 .000 \times 2)$

$=0.75 \times 11.040 .000$

$=$ Rp. 8.280.000,-

Pembiayaan : Taksiran x FTV

$=$ Rp. $8.280 .000 \times 85 \%$

$=$ Rp. 7.038.000,-(maksimal pinjaman yang bisa diberikan kepada nasabah)

$=$ Rp. 6.000.000,- (pinjaman yang diminta nasabah)

Sewa Modal : (Pinjaman $\mathrm{x}$ tarif) $\mathrm{x}$ periode gadai

$=$ Rp. $6.000 .000 \times 1.150 \% \times 4$

$=$ Rp. $\quad 276.000,-$

Maka jumlah yang harus dilunasi oleh Nasabah adalah Rp 6.276.000,- 
Tabel 3. Simulasi Pelunasan Gadai Konvensional

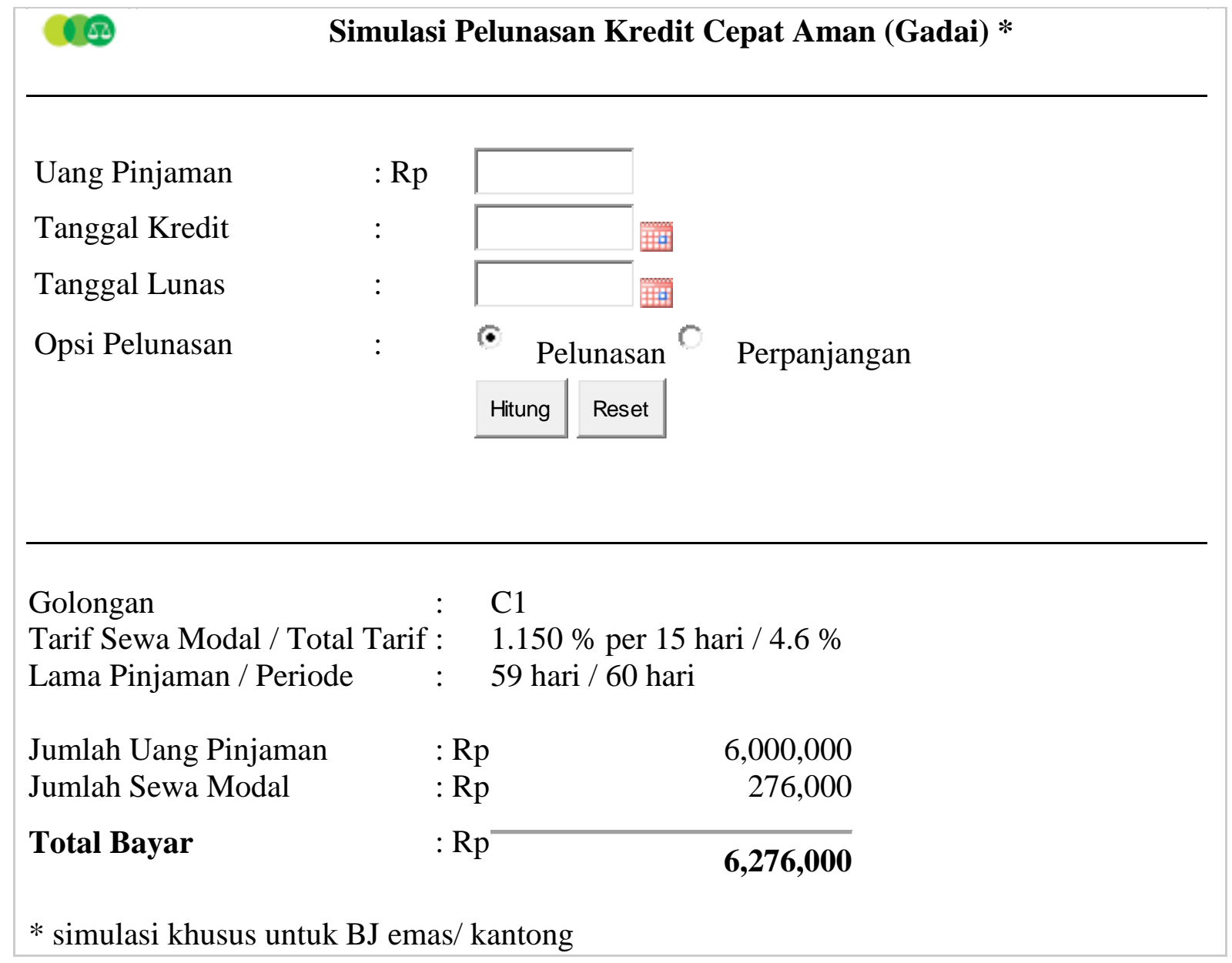

Sumber: http://www.pegadaian.co.id/simulasi-pelunasan-kca.php

\subsection{Gadai Emas Syariah}

Prinsip Gadai Emas Syariah memungut biaya berupa biaya penitipan, pemeliharaan, penjagaan, dan penaksiran. Biaya dihitung berdasarkan nilai barang (harga taksiran).

Prinsip gadai emas syariah sudah diterapkan di beberapa lembaga keuangan antara lain:

\subsubsection{Pegadaian Syariah}

Ketentuan Gadai Emas Pegadaian Syariah

1. $\mathrm{FTV}=85 \%$ (emas perhiasan) dan $90 \%$ (logam mulia) dari harga taksiran 
2. Jangka Waktu minimal 10 hari (1 periode) maksimal 120 hari (4 bulan) dapat diperpanjang.

Tabel 4. Harga Emas Pegadaian

Update: 28-12-2016

\section{Harga Emas Pegadaian}

\begin{tabular}{lr}
\hline Denominasi & Harga \\
\hline 1 gram & 586.000 \\
\hline 5 gram & 2.785 .000 \\
\hline 10 gram & 5.520 .000 \\
\hline 25 gram & 13.725 .000 \\
\hline 50 gram & 27.400 .000 \\
\hline 100 gram & 54.750 .000 \\
\hline 250 gram & 136.750 .000 \\
\hline
\end{tabular}

Sumber: http://www.pegadaian.co.id/simulasi-pelunasan-kca.php

Tabel 5. Pembiayaan Rahn Pegadaian Syariah

Pembiayaan Rahn (Gadai Syariah)

\begin{tabular}{|c|c|c|c|c|c|}
\hline \multirow{2}{*}{ Golongan } & \multicolumn{2}{|c|}{ Marhun Bih } & \multicolumn{2}{|c|}{ Tarif Ijaroh } & \multirow{2}{*}{$\begin{array}{c}\text { Lama Pinjaman } \\
\text { (hari) }\end{array}$} \\
\hline & Min & Max & Emas & Non-Emas & \\
\hline A & 50,000 & 500,000 & $\begin{array}{c}0.450 \% \mathrm{x} \\
\text { Taksiran }\end{array}$ & $\begin{array}{c}0.450 \% \text { x } \\
\text { Taksiran }\end{array}$ & $1 \mathrm{~s} / \mathrm{d} 120$ \\
\hline B1 & 500,001 & $1,000,000$ & $\begin{array}{c}0.710 \% \text { x } \\
\text { Taksiran }\end{array}$ & $\begin{array}{c}0.720 \% \mathrm{x} \\
\text { Taksiran }\end{array}$ & $1 \mathrm{~s} / \mathrm{d} 120$ \\
\hline B2 & $1,000,001$ & $2,500,000$ & $\begin{array}{c}0.710 \% \mathrm{x} \\
\text { Taksiran }\end{array}$ & $\begin{array}{l}0.720 \% \mathrm{x} \\
\text { Taksiran }\end{array}$ & $1 \mathrm{~s} / \mathrm{d} 120$ \\
\hline B3 & $2,500,001$ & $5,000,000$ & $\begin{array}{c}0.710 \% \mathrm{x} \\
\text { Taksiran }\end{array}$ & $\begin{array}{c}0.720 \% \mathrm{x} \\
\text { Taksiran }\end{array}$ & $1 \mathrm{~s} / \mathrm{d} 120$ \\
\hline $\mathrm{C} 1$ & $5,000,001$ & $10,000,000$ & $\begin{array}{c}0.710 \% \mathrm{x} \\
\text { Taksiran }\end{array}$ & $\begin{array}{c}0.720 \% \mathrm{x} \\
\text { Taksiran }\end{array}$ & $1 \mathrm{~s} / \mathrm{d} 120$ \\
\hline $\mathrm{C} 2$ & $10,000,001$ & $15,000,000$ & $\begin{array}{c}0.710 \% \mathrm{x} \\
\text { Taksiran }\end{array}$ & $\begin{array}{c}0.720 \% \mathrm{x} \\
\text { Taksiran }\end{array}$ & $1 \mathrm{~s} / \mathrm{d} 120$ \\
\hline C3 & $15,000,001$ & $20,000,000$ & $\begin{array}{c}0.710 \% \mathrm{x} \\
\text { Taksiran }\end{array}$ & $\begin{array}{c}0.720 \% \mathrm{x} \\
\text { Taksiran }\end{array}$ & $1 \mathrm{~s} / \mathrm{d} 120$ \\
\hline $\mathrm{D}$ & $20,000,001$ & $000,000,000$ & $\begin{array}{c}0.620 \% \text { x } \\
\text { Taksiran }\end{array}$ & $\begin{array}{c}0.650 \% \mathrm{x} \\
\text { Taksiran }\end{array}$ & $1 \mathrm{~s} / \mathrm{d} 120$ \\
\hline
\end{tabular}

Sumber: http://www.pegadaian.co.id/suku-bunga.php?sewa_modal 
Contoh: Simulasi Pembiayaan Gadai Emas Pegadaian Syariah

Pada tanggal 1 November 2016, Nasabah membawa emas untuk digadaikan berupa gelang bermata dengan kadar 18 karat dan berat 20 gram. Berapakah jumlah yang harus dibayar, bila Nasabah melunasi pada tanggal 29 Desember 2016 dengan uang pinjaman Rp. $6.000 .000,-?$

Pembahasan:

Periode Gadai $: 1$ November -29 Desember $=59$ hari $(4$ periode $)$

Taksiran : emas perhiasan 18 Karat berat 20 gram

$=(\mathrm{karat} / 24) \mathrm{x}$ berat emas $\mathrm{x}$ harga emas

$=18 / 24 \times(5.520 .000 \times 2)$

$=0.75 \times 11.040 .000$

$=$ Rp. 8.280.000,-

Pembiayaan : Taksiran x FTV

$=$ Rp. $8.280 .000 \times 85 \%$

$=$ Rp. 7.038.000,-(maksimal pinjaman yang bisa diberikan kepada nasabah $)$

$=$ Rp. 6.000.000,- (pinjaman yang diminta nasabah $)$

Jasa Simpan : (Taksiran x Rate) x waktu gadai

$=$ Rp. $8.280 .000 \times 0.710 \% \times 6$

$=$ Rp. $\quad 352.728,-$

Diskon $22.6 \%=$ Rp. $\quad 352.728,-\mathrm{x} 77.4 \%$

$=$ Rp. $\quad 273.011 .47$ dibulatkan menjadi Rp. 273.000,-

Maka jumlah yang harus dilunasi oleh Nasabah adalah Rp. 6.273.000,- 
Tabel 6. Simulasi Pelunasan Rahn Pegadaian Syariah

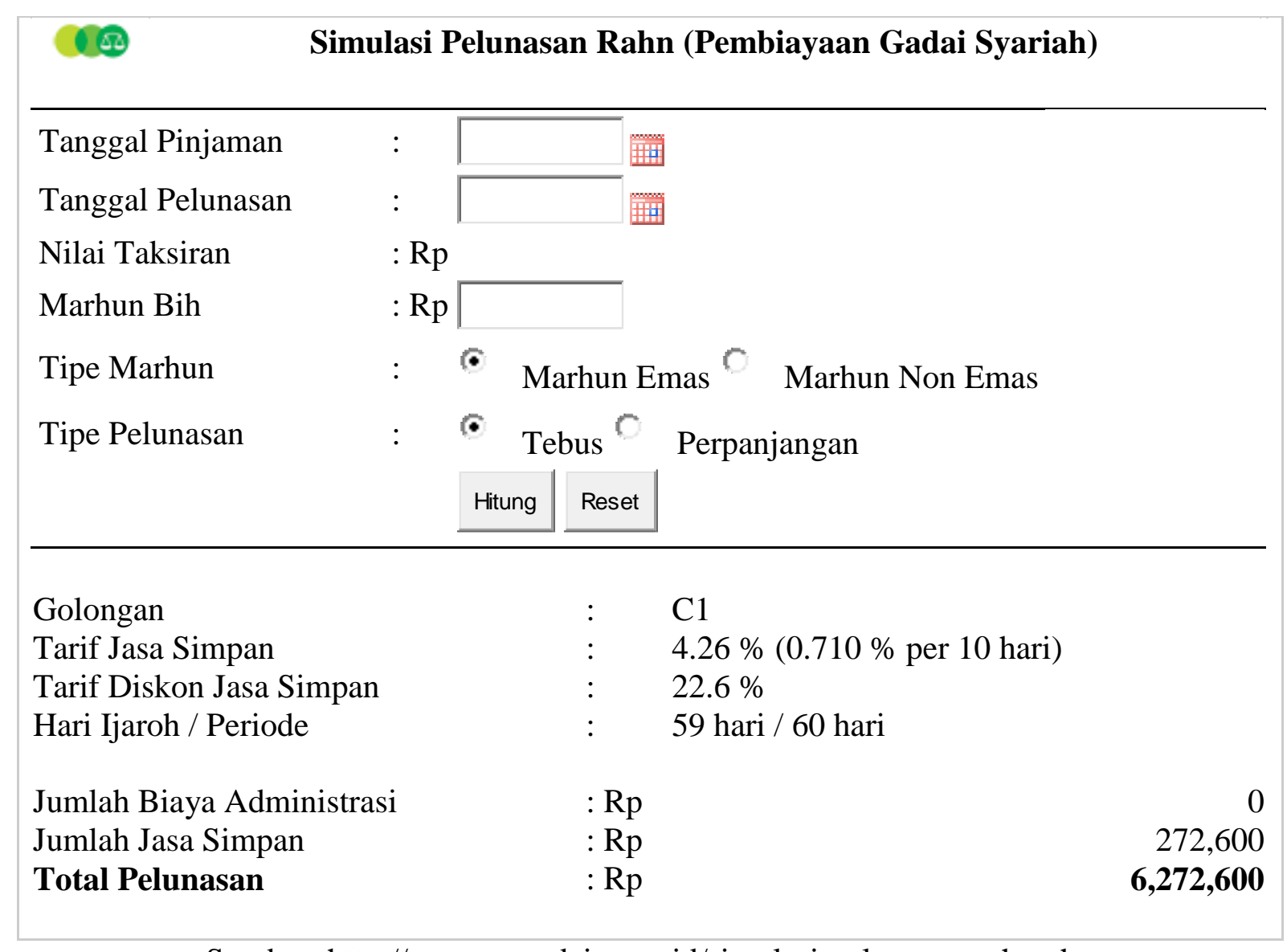

Sumber: http://www.pegadaian.co.id/simulasi-pelunasan-rahn.php

\subsubsection{Bank Syariah Mandiri (BSM)}

Ketentuan Gadai Emas BSM

1. $\mathrm{FTV}=85 \%$ (emas perhiasan) dan $90 \%$ (logam mulia) dari harga taksiran

2. Jangka Waktu minimal 15 hari maksimal 120 hari (4 bulan) dapat diperpanjang

3. Rate : $1.70 \%$ / 1 bulan. (https://www.syariahmandiri.co.id/category/consumerbanking/emas/gadai-emas-bsm/) 
Tabel 7. Info Harga Emas BSM

Last Update: 28 Des 2016

Info Harga Emas

Update HDE dan harga emas Antam per hari ini

\begin{tabular}{|r|c|c|}
\hline Gram & $\begin{array}{c}\text { Price per bar } \\
\text { (Rp) }\end{array}$ & $\begin{array}{c}\text { Price per gram } \\
(\mathbf{R p})\end{array}$ \\
\hline 250 & 136.800 .000 & 547.000 \\
100 & 54.750 .000 & 547.500 \\
50 & 27.400 .000 & 548.000 \\
\hline 25 & 13.725 .000 & 549.000 \\
10 & 5.520 .000 & 552.000 \\
\hline 5 & 2.785 .000 & 557.000 \\
\hline 4 & 2.228 .000 & 557.000 \\
\hline 3 & 1.676 .000 & 560.000 \\
\hline 2.5 & 1.405 .000 & 562.000 \\
\hline 2 & 1.132 .000 & 566.000 \\
\hline 1 & 586.000 & 586.000 \\
\hline
\end{tabular}

Sumber: http://www.syariahmandiri.co.id/

Contoh: Simulasi Pembiayaan Gadai Emas BSM

Pada tanggal 1 November 2016, Nasabah membawa emas untuk digadaikan berupa gelang bermata dengan kadar 18 karat dan berat 20 gram. Berapakah jumlah yang harus dibayar, bila Nasabah melunasi pada tanggal 29 Desember 2016 dengan uang pinjaman Rp. $6.000 .000,-?$

Pembahasan:

Periode Gadai : 1 November -29 Desember $=59$ hari $(4$ periode $)$

Taksiran : emas perhiasan 18 Karat berat 20 gram

$$
\begin{aligned}
& =(\mathrm{karat} / 24) \times \text { berat emas } \times \mathrm{HDE} \\
& =(18 / 24) \times 20 \times \mathrm{Rp} 491.500,- \\
& =0.75 \times 9.830 .000 \\
& =\text { Rp. 7.372.500,- }
\end{aligned}
$$


Pembiayaan : Taksiran x FTV

$=$ Rp. $7 \cdot 372 \cdot 500,-x 85 \%$

$=$ Rp. 6.266.625,-(maksimal pinjaman yang bisa diberikan kepada nasabah)

$=$ Rp. 6.000.000,- (pinjaman yang diminta nasabah)

Biaya Pemeliharaan: (Taksiran x Rate) x waktu gadai

$$
\begin{aligned}
& =(\operatorname{Rp~7.372.500,-} \times 1,70 \% / 1 \text { bulan }) \times 2 \text { bulan } \\
& =(\operatorname{Rp~125.332,50\times ~2~bulan~}) \\
& =\operatorname{Rp~250.665,-}
\end{aligned}
$$

Maka jumlah yang harus dilunasi oleh Nasabah adalah Rp 6.250.665,-

\subsubsection{Bank Jabar Banten (BJB) Syariah}

Ketentuan Gadai Emas BJB Syariah

1. $\mathrm{FTV}=85 \%$ (emas perhiasan) dan $90 \%$ (logam mulia) dari harga taksiran

2. Nilai pinjaman mulai Rp. $1.000 .000,-$

3. Minimal Jangka Waktu 1 bulan (1 hari sampai dengan 28, 29, 30 atau 31 hari dihitung sebulan) maksimal 120 hari (4 bulan) dapat diperpanjang

4. Minimal 16 karat

Tabel 8. Harga Emas BJB Syariah

\begin{tabular}{|c|c|}
\hline & HARGA EMAS \\
\hline Gram & Harga $(\mathrm{Rp})$ \\
\hline 5 & $\mathbf{5 4 0 . 0 0 0}$ \\
10 & 532.000 \\
25 & 518.000 \\
50 & 515.000 \\
100 & 511.000 \\
\hline
\end{tabular}

Jurnal Ilmiah Al-Syir'ah Vol. 14 No. 2 Tahun 2016

Institut Agama Islam Negeri (IAIN Manado) 


\section{Penyesuaian Harga Standar Emas Pembiayaan Mitra Emas iB Maslahah (HSE) yaitu} Rp. 541.750-/ gram

Sumber: http://www.bjbsyariah.co.id/produk-dan-jasa/produk-pembiayaan/pembiayaankonsumtif/mitra-emas-ib-maslahah/

Tabel 9. Biaya Pemeliharaan Emas BJB Syariah

\begin{tabular}{|c|c|c|}
\hline No & Karatase & Biaya Pemeliharaan (Ujroh) per gram per bulan \\
\hline 1 & 16 & Rp. 6.250 \\
\hline 2 & 17 & Rp. 6.250 \\
\hline 3 & 18 & Rp. 6.350 \\
\hline 4 & 19 & Rp. 6.350 \\
\hline 5 & 20 & Rp. 6.450 \\
\hline 6 & 21 & Rp. 6.450 \\
\hline 7 & 22 & Rp. 6.500 \\
\hline 8 & 23 & Rp. 6.500 \\
\hline 9 & 24 & Rp. 5.400 \\
\hline
\end{tabular}

Sumber: http://www.bjbsyariah.co.id/produk-dan-jasa/produk-pembiayaan/pembiayaankonsumtif/mitra-emas-ib-maslahah/

Contoh: Simulasi Pembiayaan Gadai Emas BJB Syariah

Pada tanggal 1 November 2016, Nasabah membawa emas untuk digadaikan berupa gelang bermata dengan kadar 18 karat dan berat 20 gram. Berapakah jumlah yang harus dibayar, bila Nasabah melunasi pada tanggal 29 Desember 2016 dengan uang pinjaman Rp. $6.000 .000,-?$

Pembahasan:

Periode Gadai $: 1$ November -29 Desember $=59$ hari $(2$ bulan $)$

Taksiran : emas perhiasan 18 Karat berat 20 gram

$$
\begin{aligned}
& =(\mathrm{karat} / 24) \times \text { berat emas } \times \text { HSE } \\
& =(18 / 24) \times 20 \times \mathrm{Rp} 541.750,- \\
& =0.75 \times 10.835 .000 \\
& =\text { Rp. 8.126.250,- }
\end{aligned}
$$


Pembiayaan : Taksiran x FTV

$=$ Rp. $8 \cdot 126 \cdot 250,-\mathrm{x} 85 \%$

= Rp. 6.907.312,50(maksimal pinjaman yang bisa diberikan kepada nasabah)

$=$ Rp. 6.000.000,- $($ pinjaman yang diminta nasabah $)$

Biaya Pemeliharaan:(Tabel 8)

$$
\begin{aligned}
& =(\text { biaya ujroh } 18 \mathrm{k} / \text { gram/bulan }) \times \text { berat } \times \text { waktu gadai } \\
& =(\operatorname{Rp} 6.350,-\times 20 \text { gram }) \times 2 \text { bulan } \\
& =(\operatorname{Rp~} 127.000 \times 2 \text { bulan }) \\
& =\operatorname{Rp~254.000,-}
\end{aligned}
$$

Maka jumlah yang harus dilunasi oleh Nasabah adalah Rp 6.254.000,-

\subsubsection{Unit Usaha Syariah Bank CIMB Niaga}

Ketentuan Gadai Emas UUS Bank CIMB Niaga

1. $\mathrm{FTV}=80 \%$ dari harga taksiran

2. Nilai pinjaman mulai Rp. 500.000,-

3. Minimal Jangka Waktu 15 hari (1 periode) maksimal 120 hari (4 bulan) dapat diperpanjang

4. Nasabah Wajib membuka rekening di Bank CIMB NIAGA Syariah dan Pencairan Pembiayaan harus ke Rekening Nasabah

Tabel 10. Harga Emas Antam Tanggal 28 Des 2016.

\section{Harga Emas Hari Ini}

\section{GOLD MEMBER}

Product

Jual

Beli

Emas Logam Mulia 99.99\%

508,000

495,000 
Perak SRH 99.9\%

Last Update : 28/12/2016 10:45

Sumber: https://www.antamgold.com/harga-emas-hari-ini\#popup

Tabel 11. Biaya Ujroh Jaminan Emas Bank CIMB Niaga Syariah

\begin{tabular}{|c|c|}
\hline Pembiayaan & Tarif (Equivalen) \\
\hline < Rp. 10.000 .000 & $1.5 \% /$ bulan \\
\hline$\geq$ Rp. 10.000 .000 & $1.3 \% /$ bulan \\
\hline
\end{tabular}

Sumber: https://www.cimbniaga.com/syariah/in/personal/products/financing/gold-mortgage financing.html

Contoh: Simulasi Pembiayaan Gadai Emas BJB Syariah

Pada tanggal 1 November 2016, Nasabah membawa emas untuk digadaikan berupa gelang bermata dengan kadar 18 karat dan berat 20 gram. Berapakah jumlah yang harus dibayar, bila Nasabah melunasi pada tanggal 29 Desember 2016 dengan uang pinjaman Rp. $6.000 .000,-?$

Pembahasan:

Periode Gadai : 1 November -29 Desember $=59$ hari $(2$ bulan $)$

Taksiran : emas perhiasan 18 Karat berat 20 gram

$=(\operatorname{karat} / 24) \mathrm{x}$ berat emas $\mathrm{x}$ harga emas $($ Tabel 10)

$=(18 / 24) \times 20$ x Rp 508.000,-

$=0.75 \times 10.160 .000$

$=$ Rp. 7.620.000,-

Pembiayaan : Taksiran x FTV

$=$ Rp. $7 \cdot 425.000,-x 80 \%$

= Rp. 6.096.000,-(maksimal pinjaman yang bisa diberikan kepada nasabah) 
$=$ Rp. 6.000.000,- (pinjaman yang diminta nasabah)

Biaya Pemeliharaan: (Tabel 11)

$$
\begin{aligned}
& =\text { Taksiran } x \text { rate } x \text { waktu gadai } \\
& =(\operatorname{Rp} 7.620 .000,-\times 1.5 \%) \times 2 \text { bulan } \\
& =(\operatorname{Rp~} 114.300 \times 2 \text { bulan }) \\
& =\operatorname{Rp} 228.600,-
\end{aligned}
$$

Maka jumlah yang harus dilunasi oleh Nasabah adalah Rp 6.228.600,-

\section{Kesimpulan}

Gadai Emas Syariah memiliki perbedaan mendasar dengan gadai emas konvensional dalam pengenaan biaya. Pegadaian konvensional memungut biaya dalam bentuk bunga yang bersifat akumulatif dan berlipat ganda, lain halnya dengan biaya di Pegadaian Syariah dan/atau bank syariah yang tidak berbentuk bunga, tetapi berupa biaya penitipan, pemeliharaan, penjagaan, dan penaksiran. Biaya gadai syariah lebih kecil dan hanya sekali saja.

Dari hasil observasi di atas diketahui bahwa perhitungan pembiayaan gadai emas dengan sistem syariah lebih menguntungkan bagi masyarakat dibandingkan dengan sistem konvensional. Selain itu bagi masyarakat muslim khususnya telah terhindar dari riba yang haram. Namun begitu, masih banyak umat islam yang belum memahami sistem syariah ini. Untuk itu diperlukan sosialisasi yang gencar dari berbagai pihak terutama para ulama dan tentunya dari pihak bank syariah sendiri. Semoga dengan adanya tulisan ini dapat menambah wawasan bagi umat muslim dan turut mengembangkan bisnis syariah di lingkungan kita. Amin. 


\section{Daftar Pustaka}

Antonio, Muhammad Syafi'i, 2001, Bank Syariah dari Teori ke Praktik, Jakarta: Gema Insani Press

Kasmir, 2002, Dasar-Dasar Perbankan, Jakarta: Raja Grafindo Persada

Kitab Undang-Undang Hukum Perdata

Peraturan Pemerintah Nomor 103 Tahun 2000 tentang Perusahaan Umum (Perum) Pegadaian Peraturan Bank Indonesia (PBI) Nomor/17/PBI/2008 tentang Produk Bank Syariah dan Unit Usaha Syariah (UUS)

Surat Edaran Bank Indonesia No.14/7/DPbS tanggal 29 Februari 2012 tentang Produk Qardh Beragun Emas bagi Bank Syariah dan Unit Usaha Syariah

Fatwa Dewan Syari'ah Nasional Nomor 25/DSN-MUI/III/2002 tentang Rahn

Fatwa Dewan Syari'ah Nasional Nomor 26/DSN-MUI/III/2002 tentang Rahn Emas

Pegadaian,http://www.pegadaian.co.id

Bank Syariah Mandiri, https://www.syariahmandiri.co.id

Bank Jabar Banten Syariah,http://bjbsyariah.co.id

Bank CIMB Niaga,https://www.cimbniaga.com

Ensiklopedia Bebas, https://id.wikipedia.org

Kamus Besar Bahasa Indonesia (KBBI), kamus versi online, http://kbbi.web.id 